\title{
Contrasting age-specific recruitment and survival at different spatial scales: a case study with the European storm petrel
}

\author{
Ana Sanz-Aguilar, Bruno Massa, Fabio Lo Valvo, Daniel Oro, Eduardo Minguez and \\ Giacomo Tavecchia
}

A. Sanz-Aguilar (ana.sanz@uib.es), D. Oro and G. Tavecchia, Inst. Mediterrani d'Estudis Avançats IMEDEA (CSIC-UIB), Miquel Marques 21, ES-07190 Esporles, Mallorca, Spain. - B. Massa and F. Lo Valvo, Dipartimento S.EN.FI.MI.ZO, Univ. degli Studi di Palermo, Viale delle Scienze-Parco d'Orleans, IT-90128, Palermo, Italia. - E. Minguez, Parque Natural Serra Gelada y su entorno litoral (Generalitat Valenciana), Paseo de la Carretera 34, ES-03501 Benidorm, Alicante, Spain.

\begin{abstract}
Evolutionary studies on optimal decisions or conservation guidelines are often derived by generalising patterns from a single population, while inter-population variability in life-history traits is seldom considered. We investigated here how survival and recruitment probabilities changed with age at different geographical scales using the encounter histories of 5523 European storm petrels from three Mediterranean colonies, and also how our estimates of these parameters might be expected to affect population growth rates using population matrix models. We recorded similar patterns among colonies, but also important biological differences. Local survival, recruitment and breeding success increased with age at all colonies; the most distant of three colonies (Marettimo Is.) showed the largest differences. Strikingly, differences in recruitment were also found between two adjacent colonies (two caves from Benidorm Is.). Birds marked as adults from Marettimo and Benidorm colonies had a different survival, whereas we found no differences within Benidorm. Differences in survival were no longer apparent between the two islands at the end of the study following a reduction in predation by specialist gulls at Benidorm. Since birds marked as fledglings mostly recruited near the end of the study, their overall survival was high and in turn similar among colonies. Results from our population matrix models suggested that different age-dependent patterns of demographic parameters can lead to similar population growth rates. Variability appeared to be greater for recruitment and the most sensitive parameter was adult survival. Thus conservation actions targeting this vulnerable species should focus on factors influencing adult survival. Differences in survival and recruitment among colonies could reflect the spatial heterogeneity in mortality due to predation and colony-specific density dependent processes. Results highlight the importance of taking into account the potential spatio-temporal heterogeneity among populations in vital rates, even in those traits that life-history theory considers less important in driving population dynamics.
\end{abstract}

In long-lived animals survival, accession to reproduction (recruitment) and breeding success are typically age-dependent (Newton 1989, Forslund and Pärt 1995). The agedependent pattern determines the shape of the reproductive value function, i.e. the expected contribution to future generations from individuals of a given age, which ultimately drives optimal decisions on reproductive tactics (McNamara and Houston 1996). Moreover, the value and the shape of this function determine the expected population growth rate (Morris and Doak 2002). Consequently, age-related differences in demographic parameters should have important consequences for population persistence at a local as well as metapopulation level (Hanski and Gilpin 1997, Frederiksen et al. 2005, Tavecchia et al. 2005). In long-lived species the population growth rate is highly sensitive to changes in adult survival (Saether and Bakke 2000) but because natural selection tends to reduce the temporal variability in this parameter, population dynamics are driven mainly by changes in recruitment processes and/or fertility (Gaillard et al. 2000, Tavecchia et al. 2001, Morris and Doak 2002, Weimerskirch 2002, Oro et al. 2004a).

In addition to this life-history framework, constraints imposed by spatial variation in food resources, habitat availability or predator densities can generate differences in demographic rates at multiple geographical scales across populations of the same species (Levin 1981, Rodd and Reznick 1997, Ferrer et al. 2004, Tavecchia et al. 2008) or even within populations due for instance to despotic distributions (Oro 2008). An example of these phenomena is the large variation in survival, breeding success and population dynamics of nine populations of the blacklegged kittiwake Rissa tridactyla across their geographical range (Frederiksen et al. 2005). Age of maturity, sex ratio, mortality rates and fecundity varied also among populations of guppies Poecilia reticulata according to predator pressure in each population (Reznick et al. 1990, Rodd and Reznick 1997), while the population structure in three groups of Soay sheep Ovis aries living in different parts of the same 
island was distinct, reflecting differences in survival, recruitment and dispersal rates (Coulson et al. 1999).

Results obtained from a single population can neither be taken as characteristic of the species nor exported to other populations without caution (Frederiksen et al. 2005, Breton et al. 2006). Further, comparative studies of interpopulation variation in demographic parameters are necessary to improve our understanding of evolution of life histories, population functioning and finally the scale at which management actions can be effective, especially for those species whose abundance is notoriously difficult to monitor and where long-term trends remain generally undetected (Oro and Pradel 2000, Frederiksen and Bregnballe 2001, Cam et al. 2005, Frederiksen et al. 2005, Tavecchia et al. 2008).

The aim of this study was to assess the effects of age and site (colony) on probabilities of survival, recruitment and breeding success probabilities using data from the European storm petrel Hydrobates pelagicus. We investigated the potential influence of spatial heterogeneity on demographic parameters by contrasting results from three colonies in the Mediterranean basin at two geographical scales: small (ca $0.15 \mathrm{~km})$ and large $(\mathrm{ca} 1000 \mathrm{~km})$. Estimates from these parameters were subsequently incorporated into an agestructured population model to evaluate if differences in demographic parameters among colonies may generate significant differences in the expected population growth rate.

\section{Methods}

\section{Data collection}

The European storm petrel is one of the smallest long-lived seabirds of the Order Procellariiformes (average body mass, $28 \mathrm{~g}$, Warham 1990). Storm petrels lay a single egg in natural borrows, under boulders or in crevices. The egg is incubated by both males and females for ca $40 \mathrm{~d}$ (Warham 1990). There is no particular concern for the status of the species worldwide, but the Mediterranean subspecies, $H$. $p$. melitensis, is considered vulnerable due to its decline caused by predation from human introduced species (Martin et al. 2000). Here we used long-term individual data collected at three colonies in the Mediterranean basin (Fig. 1): one located on the island of Marettimo (Egadi archipelago, Italy, $\left.37^{\circ} 58^{\prime} \mathrm{N}, 12^{\circ} 03^{\prime} \mathrm{E}\right)$; and two on the island of Benidorm (southern Spain, $38^{\circ} 30^{\prime} \mathrm{N}, 0^{\circ} 08^{\prime} \mathrm{E}$ ). The Marettimo colony is ca $1060 \mathrm{~km}$ east of Benidorm while the two colonies at Benidorm are ca $150 \mathrm{~m}$ apart. Individuals were captured on their nest during incubation or during the chick rearing period and marked with a stainless steel ring with a unique alpha-numeric code. Fledglings born in monitored nests were marked 20-50 d after hatching.

\section{Data collection at Marettimo Island}

Marking and recapture of birds at Marettimo Island was carried out from 1991-2006. Birds marked at Marettimo were divided into two groups, those ringed as fledglings (FM, for fledgling Marettimo, $\mathrm{n}=2453$ ) and those marked as adults (AM, for adult Marettimo, $n=1228$ ). The colony was visited once per year except in 1994 when it was monitored

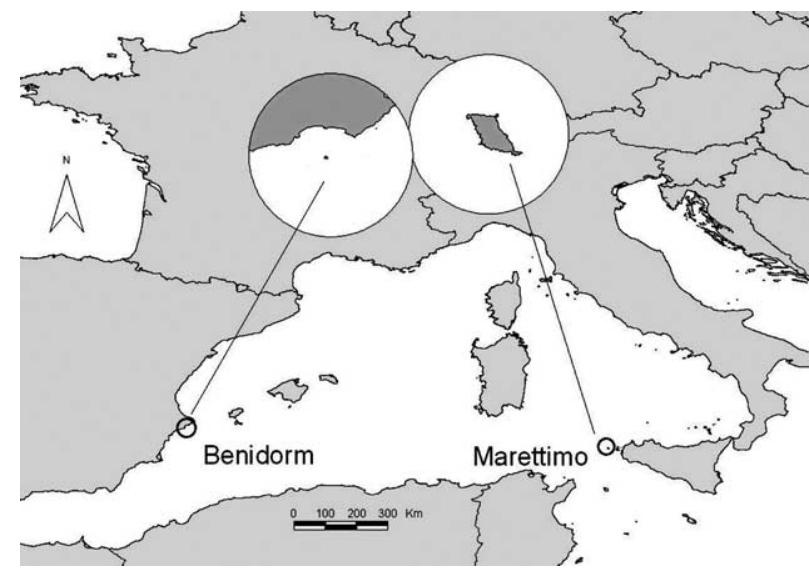

Figure 1. Location of the three study colonies: one at Marettimo Island (Italy) and two at Benidorm Island (Spain).

twice and in 1995, when it was not visited. In 1997 the colony was visited late in the season when most of the adults had already left. These discrepancies are important as they influence what can be estimated from our data. Hence, for example, survival in 1994 and 1995, are not separately estimable due to the absence of recaptures in 1995.

\section{Data collection at Benidorm Island}

At Benidorm Island, data were collected during the period 1993-2006 at two breeding colonies, cave 1 and cave 2 . The two colonies are not equivalent. Cave 1 hosts ca 200 breeding pairs, nearly twice the size of cave 2 , and is thought to have a higher predation pressure by the yellow-legged-gull Larus michahellis (Oro et al. 2005). Moreover, in 1996, a small number of artificial nest-boxes were installed inside both colonies but they were disproportionally occupied in cave 2 (de León and Mínguez 2003). As in Marettimo, birds marked at Benidorm from 1993 to 2006 were divided into two groups, those ringed as fledglings in cave 1 (FB1, for fledgling of Benidorm at cave $1, \mathrm{n}=649$ ) and in cave 2 (FB2, $\mathrm{n}=332)$; and those, of unknown age, marked as adults in both colonies (AB1, $\mathrm{n}=593$ and AB2, $\mathrm{n}=268$, for adult of Benidorm in cave 1 and 2, respectively). With the exception of one case (discarded in the present analysis), adults caught in one colony were never observed in the other. We recorded only three cases of natal dispersal, fledglings marked in one cave and found breeding in the other. These birds were assigned to the colony where they recruited. Due to difficulties associated with accessing Marettimo, breeding outcomes were only recorded at Benidorm Island and these were acquired by inspecting nests during the hatching and fledging breeding periods. Nests in which the egg did not hatch or in which individuals failed to rear their chick were considered unsuccessful (see details in Sanz-Aguilar et al. 2008). Finally, thirty-seven breeding adults and ninety-two fledglings were sexed by DNA technique (see details in Griffiths et al. 1998).

\section{Statistical analysis}

\section{Capture-mark-recapture analysis}

Local survival (survival confounded by permanent immigration out of the study areas) and recapture probabilities from birds marked at the three study sites were assessed by 
capture-mark-recapture analyses (Lebreton et al. 1992, Amstrup et al. 2005). We performed two separate analyses, one for birds marked as fledglings and a second for birds marked as adults. Although capture-mark-recapture models can be used to analyze recruitment and population growth rate (Hilton and Miller 2003), the small sample size on birds marked as fledglings precluded such analysis, and recruitment was analyzed separately (see below).

Goodness-of-fit: capture-recapture analyses typically begin with a goodness-of-fit of a model assuming full time variation for all parameters (the Cormark-Jolly-Seber (CJS) model, Lebreton et al. 1992). The goodness-of-fit test is based on specific contingency tables for each recapture occasion which can be calculated using program U-CARE 2.2.2 (Choquet et al. 2005). The program includes a specific test for transience (Test 3.SR) which assesses whether survival soon after marking is different from survival thereafter, and for trap-dependence (Test 2.CT) which tests whether recapture probability at time i depends on the past capture history (see more details in Supplementary material Appendix 1). With the exception of group $A B 2$, we found a significant transient effect in all groups (Supplementary material Appendix 1). In birds marked as fledglings, a transient effect represents a lower local survival of youngest birds while in birds marked as breeders transience may reflect colony abandonment (birds leaving the study area), low survival in response to the capture, and/ or a survival cost of first reproduction (Pradel et al. 1997, Sanz-Aguilar et al. 2008). To appropriately account for transience in our data, we modified our starting CJS model to include an effect of age for all groups except AB2. Remaining heterogeneity was accounted for by scaling model deviances using a variance inflation factor, $\hat{\mathrm{c}}: \hat{\mathrm{c}}=$ 1.45 for birds marked as fledglings and $\hat{c}=1.26$ for birds marked as adults (Supplementary material Appendix 1).

Model selection procedure: model selection was based on the Akaike's information criterion adjusted for small sample size (c) and overdispersion (Q) calculated as

$\mathrm{QAIC}_{\mathrm{c}}=\frac{\mathrm{dev}}{\hat{\mathrm{c}}}+2 \times \mathrm{np}$,

where dev is model deviance; $\hat{c}$ is the variance inflation factor; and $\mathrm{np}$ the number of separately identifiable parameters in the model (Burnham and Anderson 2002). Models were built and fit to the data using program M-SURGE (Choquet et al. 2004, 2006). Additionally for each model $\mathrm{i}$, we calculated the Akaike weights, $\mathrm{w}_{\mathrm{i}}$, as an index of its relative plausibility (Burnham and Anderson 2002). Estimates of survival and recapture probabilities were obtained by model averaging in which each model contributed to the final estimate according to its Akaike weight (Burnham and Anderson 2002). Evidence ratios were calculated to measure the magnitude of the difference between model-i and model- $\mathrm{j}$ as $\mathrm{w}_{\mathrm{i}} / \mathrm{w}_{\mathrm{j}}$.

Analysis of birds marked as fledglings: despite the high number of petrels marked as fledglings $(\mathrm{n}=3434),<8 \%$ were later recaptured as breeders (7 and $6 \%$ at Marettimo and Benidorm, respectively). For this reason we built models without the effect of time on survival and recapture parameters, with the exception of the model to assess the goodness-of-fit. Recapture probability in 1995 and 1997 at Marettimo was fixed to " 0 ". In addition, we set survival of ages 1 and 2 from birds at Marettimo equal given the low number of birds that recruited before age 3. At Benidorm recapture parameters for age 1 and 2 were fixed to 0 since no birds were caught recruiting before $3 \mathrm{yr}$ old; consequently only the product of survival from age 1 to 3 was estimable from our analysis of the Benidorm fledgling dataset. Survival of birds aged from 3 to 15 at Marettimo and from 4 to 13 in caves 1 and 2 at Benidorm were combined in a single age class for each colony. We began by modelling the effect of age on recapture probability and then we modelled the effect of the colony on survival. For recapture probability we considered up to 6 age classes (from 1 to $5 \mathrm{yr}$ old, older birds grouped together); additional classes did not improve model fit (results not shown). As we had not a priori biological information or hypotheses about the age-dependent patterns of recruitment (i.e. the age-dependent capture probability) and several models with different recapture structures were tied in terms of QAICc (Results), we tested models including all the structures of recapture and survival tied; finally we calculated averaged parameter estimates of such models.

Analysis of birds marked as adults: the analysis of birds marked as adults followed the same procedure of the one of birds marked as fledgling. The high number of petrels marked as adults, and their high recapture probabilities allowed an extensive modelling of the effects considered without additional assumptions.

\section{Recruitment probabilities}

The observed number of birds that recruited at different ages to their natal colonies (Fig. 2) cannot be taken as an estimate of the age-dependent recruitment because a certain number of birds may breed undetected. Clobert et al. (1994) proposed a method that makes use of the agedependent capture probability, $\mathrm{p}_{\mathrm{j}}$, to estimate the recruitment probabilities, $B_{j}$, at age $j$. Assuming that full recruitment is attained at age $\mathrm{k}$ and birds of this age do not skip reproduction, $B_{j}$ can be estimated as the ratio $\mathrm{p}_{\mathrm{j}} / \mathrm{p}_{\mathrm{k}}$. Variance of $\mathrm{B}_{j}$ can be calculated using the $\delta$-method (Morgan 2000). Although the method is not reliable for long-lived species that breed intermittently (Clobert et al. 1994), recent evidence indicated that reproductive skipping in the European storm petrel is rare (Sanz-Aguilar et al. 2008).

\section{Breeding success and sex ratio at fledgling}

We applied generalized linear mixed models (McCulloch and Searle 2001) to examine the effect of breeding colony and age on breeding success using data from 60 breeding adults marked as fledglings collected at Benidorm. Breeding success was modelled as a binary variable $(1=$ successful, $0=$ unsuccessful) using a logit-link function with binomial error distribution and the glmmML function available in the open source software $\mathrm{R}<$ www.R-project.org/>. Individual identity was treated as a random effect to correct for the multiple entries from the same birds and age $(5$ classes, for birds aged 3, 4, 5, 6, and older) and breeding colony as fixed effects. Model selection followed the same procedure and criteria as in capture-mark-recapture analyses (see above). In addition, using data from 92 molecularly sexed fledglings born in 2005 at Benidorm, 

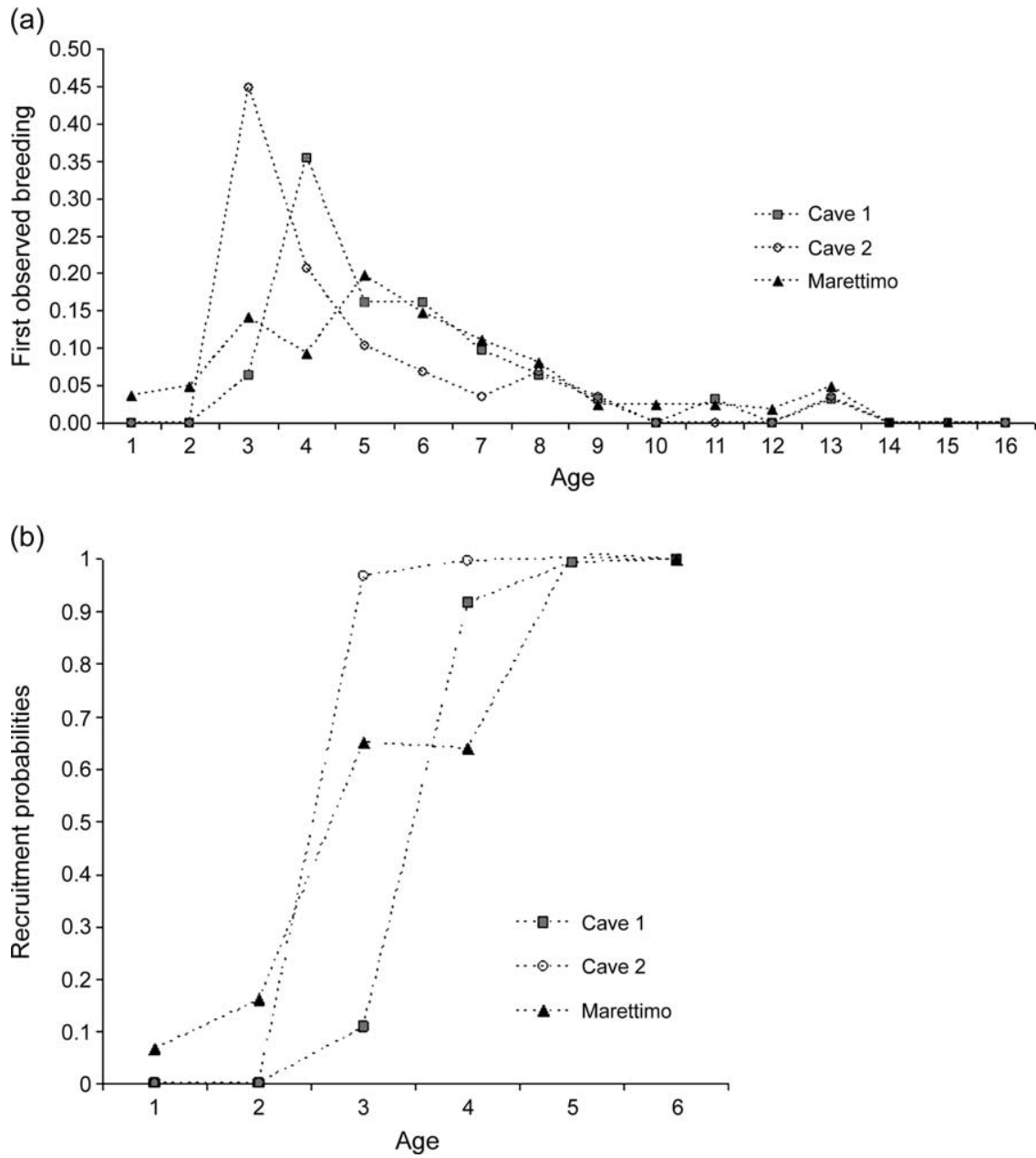

Figure 2. (a) Age-dependent proportion of first observed breeding at Marettimo and at caves 1 and 2 at Benidorm Island. About 7 and $6 \%$ of the birds marked at fledging returned to breed at their natal colony in Marettimo $(\mathrm{n}=169)$ and Benidorm island $(\mathrm{n}=60)$, respectively. (b) Age-dependent recruitment probabilities of European storm petrels breeding at Marettimo and at cave 1 and cave 2 at Benidorm Island.

sex ratio was obtained as the mean and $95 \%$ credible intervals of the posterior distribution of the parameter (i.e. female proportion) calculated by means of Markov Chain Monte Carlo simulations using the Bayesian software WinBUGS 14, after running 100000 iterations. Since we had no prior information on the study system regarding sex ratio we modelled the marginal distribution of the parameter by means of a uniform distribution $[0,1]$.

\section{Population matrix modelling}

We combined model averaged estimates of survival, recruitment and breeding success from the analyses of birds ringed as fledglings into a demographic matrix model to calculate a colony specific growth rates, $\lambda$ (Caswell 2001). The variance of $\lambda$ was estimated as

$\sum\left(\frac{\partial \lambda}{\partial \theta}\right)^{2} \sigma_{\theta}^{2}$

where $\sigma_{\theta}^{2}$ was the variance of the element of the matrix and $\frac{\partial \lambda}{\partial \theta}$, its sensitivity, i.e. the effect of a change in a given parameter of the model on $\lambda$ (Lande 1988). Note that the breeding success of birds breeding at Marettimo was not available so we used instead the low predation pressure value from Benidorm (cave 2; Supplementary material Table S2 in Appendix 2).

\section{Results}

\section{Capture-mark-recapture analysis}

\section{Analysis of birds marked as fledglings}

Observed natal philopatry, i.e. the proportion of birds marked as young that came back to their natal colony to breed and were detected, was similar between Marettimo and Benidorm, 7 and 6\% respectively. Most of the birds marked as fledglings that came back to breed at their natal colonies, did so toward the end of the study: at Marettimo the median of the distribution of returns from 1993 to 2006 was 2002; at cave 1 and cave 2 at Benidorm medians were 2002 and 2005 respectively. Despite the proximity of the two cave colonies at Benidorm, observed natal philopatry at Benidorm was high: ca $95 \%$ of the captured birds that returned $(96.7$ and $93.3 \%$ in cave 1 and cave 2, respectively) recruited into their natal colony. Extremely 
high natal philopatry was also observed at Marettimo, where most birds recruited in the same area of the cave where they hatched (Valvo and Massa 2000). Data from Benidorm suggested that males are more philopatric than females $\left(67 \%\right.$ of birds recaptured as breeders were males, $\chi_{1}^{2}$ $=4.568, p=0.03)$. Part of this difference may be due to the fact that the sex ratio at fledgling was male biased. Indeed, when the proportion of philopatric birds was related to sex ratio at fledging (see below) we did not find significant differences in philopatry between sexes $\left(\chi_{1}^{2}=\right.$ $2.099, \mathrm{p}=0.15)$. There was a marked difference in the earliest observed age of first breeding between the three colonies (Fig. 2): the earliest detected age of first reproduction at Benidorm Island was 3 while in Marettimo 2.7\% (6/2264) of the petrels came back to breed at age 1 .

We began the capture-recapture analyses by modelling recapture probabilities at Marettimo (models $1 \mathrm{~F}$ to 6F; Table $1)$. Including the effect of age in recapture probability reduced substantially the QAICc values (models $2 \mathrm{~F}$ to $6 \mathrm{~F}$; Table 1). A model in which recapture parameters varied as a function of age until age 5 (model 5F; Table 1) presented the lowest QAICc. From such model we selected the structure of recapture probabilities for Marettimo to modelling recapture probabilities at both Benidorm colonies, although model $5 \mathrm{~F}$ was tied in terms of QAICc with models $3 \mathrm{~F}, 4 \mathrm{~F}$ and $6 \mathrm{~F}$ (Table 1). For the data from cave 1 , the model that presented the lowest QAICc was model 7F (Table 1), in which recapture parameters varied as a function of age until age 4 . This model was selected to modelling recapture probabilities at cave 2 , although the model was tied with models $8 \mathrm{~F}$ and $9 \mathrm{~F}$ (Table 1) in terms of QAICc. Model 7F (3 age classes) was also the best model in terms of QAICc for the data from cave 2 (Table 1) but again other models (models 10F, 11F and 12F; Table 1) were supported.

For survival, Akaike weights marginally supported a model in which survival differed across colonies at Benidorm Island but cave 2 was similar to the estimate from Marettimo (model 14F; Table 1). Overall, models 7F, 13F, and 15F were also supported. At this point, in order to take into account uncertainty in model selection, we built new models including different combinations of the structures of recapture and survival probabilities that were previously supported (models 16F to 27F; Table 1). Note that models with other possible combinations of recapture and survival structures were not retained (Akaike weights $<0.1$, results not shown). Model 14F (Table 1) was the best in terms of

Table 1. Modelling local survival and recapture probabilities based on capture-recapture data from birds marked as fledglings at three colonies (caves 1 and 2 at Benidorm Island, Spain, noted B1 and B2, and one colony at Marettimo, Italy, denoted M). Notation: np, number of parameters in the model; dev = deviance; QAICc =Akaike's information criterion adjusted for small sample size (c) and overdispersion (Q); $\triangle$ QAICC = the difference in QAICc between the current and the model with the lowest QAICc; $w=$ Akaike weigths, " $\mathrm{t}$ " =time effect, "a" = age effect. Age structure is summarized in parentheses: the notation i:j means that the structure assumed a single parameter from age $\mathrm{i}$ to age $j$, while the notation $i_{-} j$ indicates that there is a parameter from each age class from $\mathrm{i}$ to $\mathrm{j}$. For example, the notation "a(1:2,3_15)" indicates two specific parameters, one for birds aged 1 and $2 \mathrm{yr}$ old and a second for birds older than 2 . Note that recapture probability of birds aged 1 and 2 was fixed to 0 at Benidorm colonies as no birds came back to breed before age 3. Colony specific parameters are separated by the symbol " $/ "$. Symbol " $/+l^{\prime \prime}$ indicates parallel variation among colonies and models without this notation include colony interaction terms. Symbol " $="$ " indicates equality among groups (i.e. colonies). The best model (highest QAICc weight) is shown in bold text.

\begin{tabular}{|c|c|c|c|c|c|c|c|}
\hline Model & Recapture & Survival & $\mathrm{np}$ & dev & QAICc & $\triangle \mathrm{QAICC}$ & w \\
\hline $1 \mathrm{~F}$ & M/B1/B2 & $\mathrm{M} \mathrm{a}(1: 2,3: 15) / \mathrm{B} 1 \mathrm{a}(1: 3,4: 13) / \mathrm{B} 2 \mathrm{a}(1: 3,4: 13)$ & 9 & 2919.85 & 2031.7 & 68.00 & 0.00 \\
\hline $2 \mathrm{~F}$ & $\mathrm{M} \mathrm{a}(1,2: 15) / \mathrm{B} 1 / \mathrm{B} 2$ & $\mathrm{M} \mathrm{a}(1: 2,3: 15) / \mathrm{B} 1 \mathrm{a}(1: 3,4: 13) / \mathrm{B} 2 \mathrm{a}(1: 3,4: 13)$ & 10 & 2867.39 & 1997.5 & 33.82 & 0.00 \\
\hline $3 \mathrm{~F}$ & $\mathrm{M} \mathrm{a}\left(1 \_2,3: 15\right) / \mathrm{B} 1 / \mathrm{B} 2$ & $\mathrm{M} \mathrm{a}(1: 2,3: 15) / \mathrm{B} 1 \mathrm{a}(1: 3,4: 13) / \mathrm{B} 2 \mathrm{a}(1: 3,4: 13)$ & 11 & 2838.28 & 1979.4 & 15.74 & 0.00 \\
\hline $4 \mathrm{~F}$ & $\mathrm{M} \mathrm{a}\left(1 \_3,4: 15\right) / \mathrm{B} 1 / \mathrm{B} 2$ & $\mathrm{M} \mathrm{a}(1: 2,3: 15) / \mathrm{B} 1 \mathrm{a}(1: 3,4: 13) / \mathrm{B} 2 \mathrm{a}(1: 3,4: 13)$ & 12 & 2835.82 & 1979.7 & 16.05 & 0.00 \\
\hline $5 \mathrm{~F}$ & $\mathrm{M} \mathrm{a}\left(1 \_4,5: 15\right) / \mathrm{B} 1 / \mathrm{B} 2$ & $\mathrm{M} \mathrm{a}(1: 2,3: 15) / \mathrm{B} 1 \mathrm{a}(1: 3,4: 13) / \mathrm{B} 2 \mathrm{a}(1: 3,4: 13)$ & 13 & 2828.69 & 1976.8 & 13.13 & 0.00 \\
\hline $6 \mathrm{~F}$ & $\mathrm{M} \mathrm{a}\left(1 \_5,6: 15\right) / \mathrm{B} 1 / \mathrm{B} 2$ & $\mathrm{M} \mathrm{a}(1: 2,3: 15) / \mathrm{B} 1 \mathrm{a}(1: 3,4: 13) / \mathrm{B} 2 \mathrm{a}(1: 3,4: 13)$ & 14 & 2828.69 & 1978.8 & 15.13 & 0.00 \\
\hline $7 \mathrm{~F}$ & $\mathrm{M} \mathrm{a}\left(1 \_4,5: 15\right) / \mathrm{B} 1 \mathrm{a}(3,4: 13) / \mathrm{B} 2$ & $\mathrm{M} \mathrm{a}(1: 2,3: 15) / \mathrm{B} 1 \mathrm{a}(1: 3,4: 13) / \mathrm{B} 2 \mathrm{a}(1: 3,4: 13)$ & 14 & 2807.31 & 1964.1 & 0.39 & 0.11 \\
\hline $8 \mathrm{~F}$ & $\mathrm{M} \mathrm{a}\left(1 \_4,5: 15\right) / \mathrm{B} 1 \mathrm{a}\left(3 \_4,5: 13\right) / \mathrm{B} 2$ & $\mathrm{M} \mathrm{a}(1: 2,3: 15) / \mathrm{B} 1 \mathrm{a}(1: 3,4: 13) / \mathrm{B} 2 \mathrm{a}(1: 3,4: 13)$ & 15 & 2805.65 & 1964.9 & 1.24 & 0.07 \\
\hline $9 \mathrm{~F}$ & $\mathrm{M} \mathrm{a}\left(1 \_4,5: 15\right) / \mathrm{B} 1 \mathrm{a}\left(3 \_5,6: 13\right) / \mathrm{B} 2$ & $\mathrm{M} \mathrm{a}(1: 2,3: 15) / \mathrm{B} 1 \mathrm{a}(1: 3,4: 13) / \mathrm{B} 2 \mathrm{a}(1: 3,4: 13)$ & 16 & 2805.6 & 1966.9 & 3.21 & 0.03 \\
\hline $10 \mathrm{~F}$ & $\begin{array}{l}\mathrm{M} \mathrm{a}\left(1 \_4,5: 15\right) / \mathrm{B} 1 \mathrm{a}(3,4: 13) / \mathrm{B} 2 \\
\mathrm{a}(3,4: 13)\end{array}$ & $\mathrm{M} \mathrm{a}(1: 2,3: 15) / \mathrm{B} 1 \mathrm{a}(1: 3,4: 13) / \mathrm{B} 2 \mathrm{a}(1: 3,4: 13)$ & 15 & 2807.25 & 1966 & 2.34 & 0.04 \\
\hline $11 \mathrm{~F}$ & $\begin{array}{l}\mathrm{M} \mathrm{a}\left(1 \_4,5: 15\right) / \mathrm{B} 1 \mathrm{a}(3,4: 13) / \mathrm{B} 2 \\
\mathrm{a}\left(3 \_4,5: 13\right)\end{array}$ & $\mathrm{M} \mathrm{a}(1: 2,3: 15) / \mathrm{B} 1 \mathrm{a}(1: 3,4: 13) / \mathrm{B} 2 \mathrm{a}(1: 3,4: 13)$ & 16 & 2807.24 & 1968 & 4.34 & 0.02 \\
\hline $12 \mathrm{~F}$ & $\begin{array}{l}\mathrm{M} \mathrm{a}\left(1 \_4,5: 15\right) / \mathrm{B} 1 \mathrm{a}(3,4: 13) / \mathrm{B} 2 \\
\mathrm{a}\left(3 \_5,6: 13\right)\end{array}$ & $\mathrm{M} \mathrm{a}(1: 2,3: 15) / \mathrm{B} 1 \mathrm{a}(1: 3,4: 13) / \mathrm{B} 2 \mathrm{a}(1: 3,4: 13)$ & 17 & 2807.01 & 1969.9 & 6.18 & 0.01 \\
\hline $13 \mathrm{~F}$ & $\mathrm{M} \mathrm{a}\left(1 \_4,5: 15\right) / \mathrm{B} 1 \mathrm{a}(3,4: 13) / \mathrm{B} 2$ & $\mathrm{M} \mathrm{a}(1: 2,3: 15) / \mathrm{B} 1 \mathrm{a}(1: 3,4: 13)=\mathrm{B} 2 \mathrm{a}(1: 3,4: 13)$ & 12 & 2820.03 & 1968.9 & 5.16 & 0.01 \\
\hline $14 \mathrm{~F}$ & M a(1_4,5:15)/B1 a(3,4:13)/B2 & $\mathrm{Ma}(1: 2,3: 15)=\mathrm{B} 2 \mathrm{a}(1: 3,4: 13) / \mathrm{B} 1 \mathrm{a}(1: 3,4: 13)$ & 12 & 2812.55 & 1963.7 & 0.00 & 0.14 \\
\hline $15 \mathrm{~F}$ & M a(1_4,5:15)/B1 a(3,4:13)/B2 & $\mathrm{Ma}(1: 2,3: 15)=\mathrm{B} 1 \mathrm{a}(1: 3,4: 13)=\mathrm{B} 2 \mathrm{a}(1: 3,4: 13)$ & 10 & 2825.25 & 1968.5 & 4.76 & 0.01 \\
\hline $16 \mathrm{~F}$ & $\mathrm{M} \mathrm{a(1 \_ 2,3:15)/B1(3,4:13)/B2}$ & $\mathrm{M} \mathrm{a}(1: 2,3: 15)=\mathrm{B} 2 \mathrm{a}(1: 3,4: 13) / \mathrm{B} 1 \mathrm{a}(1: 3,4: 13)$ & 10 & 2819.19 & 1964.26 & 0.57 & 0.10 \\
\hline $17 \mathrm{~F}$ & $\mathrm{M} \mathrm{a}\left(1 \_3,4: 15\right) / \mathrm{B} 1(3,4: 13) / \mathrm{B} 2$ & $\mathrm{M} \mathrm{a}(1: 2,3: 15)=\mathrm{B} 2 \mathrm{a}(1: 3,4: 13) / \mathrm{B} 1 \mathrm{a}(1: 3,4: 13)$ & 11 & 2817.58 & 1965.26 & 1.57 & 0.06 \\
\hline $18 \mathrm{~F}$ & $\mathrm{M} \mathrm{a(1 \_ 5,6:15)/B1} \mathrm{a(3,4:13)/B2}$ & $\mathrm{M} \mathrm{a}(1: 2,3: 15)=\mathrm{B} 2 \mathrm{a}(1: 3,4: 13) / \mathrm{B} 1 \mathrm{a}(1: 3,4: 13)$ & 13 & 2812.09 & 1965.37 & 1.68 & 0.06 \\
\hline $19 \mathrm{~F}$ & $\mathrm{M} \mathrm{a}\left(1 \_4,5: 15\right) / \mathrm{B} 1 \mathrm{a}\left(3 \_4,5: 13\right) / \mathrm{B} 2$ & $\mathrm{M} \mathrm{a}(1: 2,3: 15)=\mathrm{B} 2 \mathrm{a}(1: 3,4: 13) / \mathrm{B} 1 \mathrm{a}(1: 3,4: 13)$ & 13 & 2810.89 & 1964.55 & 0.86 & 0.09 \\
\hline $20 \mathrm{~F}$ & $\mathrm{M} \mathrm{a}\left(1 \_4,5: 15\right) / \mathrm{B} 1 \mathrm{a}\left(3 \_5,6: 13\right) / \mathrm{B} 2$ & $\mathrm{M} \mathrm{a}(1: 2,3: 15)=\mathrm{B} 2 \mathrm{a}(1: 3,4: 13) / \mathrm{B} 1 \mathrm{a}(1: 3,4: 13)$ & 14 & 2810.84 & 1966.51 & 2.82 & 0.03 \\
\hline $21 \mathrm{~F}$ & $\begin{array}{l}\mathrm{M} \mathrm{a}\left(1 \_4,5: 15\right) / \mathrm{B} 1 \mathrm{a}(3,4: 13) / \mathrm{B} 2 \\
\mathrm{a}(3,4: 13)\end{array}$ & $\mathrm{M} \mathrm{a}(1: 2,3: 15)=\mathrm{B} 2 \mathrm{a}(1: 3,4: 13) / \mathrm{B} 1 \mathrm{a}(1: 3,4: 13)$ & 13 & 2811.73 & 1965.12 & 1.43 & 0.07 \\
\hline $22 \mathrm{~F}$ & $\begin{array}{l}\mathrm{M} \mathrm{a}\left(1 \_4,5: 15\right) / \mathrm{B} 1 \mathrm{a}(3,4: 13) / \mathrm{B} 2 \\
\mathrm{a}\left(3 \_4,5: 13\right)\end{array}$ & $\mathrm{M} \mathrm{a}(1: 2,3: 15)=\mathrm{B} 2 \mathrm{a}(1: 3,4: 13) / \mathrm{B} 1 \mathrm{a}(1: 3,4: 13)$ & 14 & 2811.56 & 1967.01 & 3.32 & 0.03 \\
\hline $23 \mathrm{~F}$ & $\begin{array}{l}\mathrm{M} \mathrm{a}\left(1 \_4,5: 15\right) / \mathrm{B} 1 \mathrm{a}(3,4: 13) / \mathrm{B} 2 \\
\mathrm{a}\left(3 \_5,6: 13\right)\end{array}$ & $\mathrm{M} \mathrm{a}(1: 2,3: 15)=\mathrm{B} 2 \mathrm{a}(1: 3,4: 13) / \mathrm{B} 1 \mathrm{a}(1: 3,4: 13)$ & 15 & 2811.55 & 1969.00 & 5.31 & 0.01 \\
\hline $24 \mathrm{~F}$ & $\mathrm{M}$ a(1_2,3:15)/B1(3, 4:13)/B2 & $\mathrm{M} \mathrm{a}(1: 2,3: 15) / \mathrm{B} 1 \mathrm{a}(1: 3,4: 13) / \mathrm{B} 2 \mathrm{a}(1: 3,4: 13)$ & 12 & 2816.90 & 1966.69 & 3.00 & 0.03 \\
\hline $25 \mathrm{~F}$ & $\mathrm{M} \mathrm{a}\left(1 \_3,4: 15\right) / \mathrm{B} 1(3,4: 13) / \mathrm{B} 2$ & $\mathrm{M} \mathrm{a}(1: 2,3: 15) / \mathrm{B} 1 \mathrm{a}(1: 3,4: 13) / \mathrm{B} 2 \mathrm{a}(1: 3,4: 13)$ & 13 & 2814.44 & 1967.00 & 3.30 & 0.03 \\
\hline $26 \mathrm{~F}$ & $\mathrm{M} \mathrm{a}\left(1 \_5,6: 15\right) / \mathrm{B} 1 \mathrm{a}(3,4: 13) / \mathrm{B} 2$ & $\mathrm{M} \mathrm{a}(1: 2,3: 15) / \mathrm{B} 1 \mathrm{a}(1: 3,4: 13) / \mathrm{B} 2 \mathrm{a}(1: 3,4: 13)$ & 15 & 2807.30 & 1966.07 & 2.38 & 0.04 \\
\hline
\end{tabular}


QAICc w, nevertheless models $7 \mathrm{~F}$ to $13 \mathrm{~F}$ and $15 \mathrm{~F}$ to $26 \mathrm{~F}$ (Table 1) were also supported, so we calculated model averaged estimates of recapture and survival probabilities from the full model set. Model averaged estimates of survival probabilities indicated a survival probability of 0.57 (SE: 0.05 ) for birds aged 1 and 0.89 (SE: 0.03) from birds older than $2 \mathrm{yr}$ old in Marettimo; 0.47 (SE: 0.04) and 0.55 (SE: 0.03 ) for birds aged $<4$ and 0.86 (SE: 0.04) and 0.94 (SE: 0.01 ) for older birds breeding in caves 1 and 2, respectively.

The observed number of petrels that returned to the colonies (i.e. without correcting for recapture probabilities) is shown in Fig. 2a. This pattern was in agreement to the model averaged estimates of recapture probability, which we used to estimate recruitment probabilities: although petrels in Benidorm Island started to breed at older ages than in Marettimo, the analysis indicated that the full recruitment was reached earlier (Fig. 2b; Supplementary material Appendix 2, Table S2).

\section{Analysis of birds marked as adults}

We started the analysis by modelling recapture probabilities (model 1A; Table 2). Following previous analysis of these data (Tavecchia et al. 2008) we used a linear trend to model recapture probabilities from cave 2 (Benidorm); annual variation was fitted to Marettimo and in cave 1 (model 2A; Table 2). Models without time effects in recapture probabilities were strongly rejected $(\triangle$ QAICc $>10$, results not shown). It is likely that the linear increase of the recapture probabilities in cave 2 was due to the progressive occupancy of artificial nest boxes that did not occur in cave 1 (Tavecchia et al. 2008; Fig. 3a). At Marettimo and in cave 1 from Benidorm recapture probabilities varied annually, probably due to differences in field effort invested in capture (Fig. 3a).

Survival was modelled by contrasting models in which survival probability varied over time (models $1 \mathrm{~A}-6 \mathrm{~A}$; Table 2 ), in parallel among colonies, i.e. no interaction between colonies and time (models 7A-9A; Table 2), and was constant over time and/or colonies (models 10A and 11A; Table 2). Akaike weights showed that models without the interaction term between time and colony were more plausible (models 7A-9A; Table 2). We then tested for the effect of colony on survival of both newly marked birds (models 3A, 6A and 8A-11A; Table 2) and resident birds, at large (i.e. Benidorm vs Marettimo, models $4 \mathrm{~A}$ and 10A;
Table 2) and small scales (i.e. cave 1 vs cave 2 at Benidorm, models 5A-8A and 10A; Table 2). A model with a parallel variation over time in survival probabilities between newly marked birds and residents, no differences between newly marked birds at Benidorm and Marettimo and no differences between residents in caves 1 and 2 from Benidorm (model 8A; Table 2) was retained as the most plausible model $(\mathrm{w}=0.58)$. Evidence ratios showed that this model was tied with model 7A, which included differences in survival probabilities between newly marked birds at Marettimo and Benidorm, and model 9A which included differences in survival probabilities between residents at all colonies (Table 2). Model averaged estimates showed that local survival for newly marked birds at Marettimo and Benidorm was similar (Fig. 3b) and resident survival probability was higher at Marettimo than at Benidorm, where survival were similar between caves (Fig. 3c). Models without a colony effect (model 10A; Table 2) or an effect of time (model 11A; Table 2) on survival were not retained.

\section{Breeding success and sex ratio at fledging in Benidorm Island}

The effects of age and colony on breeding success were modelled from the breeding output of birds marked as fledglings (models 1-14; Table 3a). The highest Akaike weight was from a model in which the breeding success varied in parallel between colonies as a function of age until age 4 (model 4; Table 3a). Nevertheless, evidence ratios showed that this model was only 1.14 times more likely than a model without a colony effect (model 3; Table 3a) and tied for the best model status with all other models with the exception of models 11 and 14 (Table 3a). The average (and SE) breeding success was 0.53 (0.05) (model 1; Table $3 \mathrm{a}), 0.50(0.06)$ and $0.57(0.07)$ in caves 1 and 2 respectively (model 2; Table 3a). Model averaged estimates from GLM mixed models (models 1-14; Table 3a, b) indicated that birds $<4$ yr old had a lower breeding success than older birds (Table 3b). The breeding success of birds aged 4, 5 and older was very similar (Table $3 b$ ).

Results from sex ratio Bayesian analysis showed that the proportion of males was 0.56 (95\% credible interval $0.46-$ $0.66)$ and that the sex ratio of fledglings was slightly male

Table 2. Modelling local survival and recapture probabilities based on capture-recapture data from birds marked as adults at three colonies (caves 1 and 2 at Benidorm Island, Spain, noted B1 and B2, and one colony at Marettimo, Italy, denoted M. Notation as in Table 1. In addition superscript " $\mathrm{tr}^{\prime}$ " and "res" indicate parameters for newly marked birds and resident respectively. A linear trend in time was noted " $\mathrm{T}$ ". Models with the higher w are in bold.

\begin{tabular}{|c|c|c|c|c|c|c|c|}
\hline Model & Recapture & Survival & $\mathrm{np}$ & dev & QAICc & $\triangle \mathrm{QAICC}$ & w \\
\hline $1 \mathrm{~A}$ & $\mathrm{M}(\mathrm{t}) / \mathrm{B} 1(\mathrm{t}) / \mathrm{B} 2(\mathrm{~T})$ & $\mathrm{M}_{\mathrm{tr}}(\mathrm{t}) / \mathrm{B} 1_{\mathrm{tr}}(\mathrm{t}) / \mathrm{M}_{\text {res }}(\mathrm{t}) / \mathrm{B} 1_{\text {res }}(\mathrm{t}) / \mathrm{B} 2_{\text {res }}(\mathrm{t})$ & 94 & 6645.07 & 5461.86 & 22.62 & 0.00 \\
\hline $2 \mathrm{~A}$ & $\mathrm{M}(\mathrm{t}) / \mathrm{B} 1(\mathrm{t}) / \mathrm{B} 2(\mathrm{~T})$ & $\mathrm{M}_{\mathrm{tr}}(\mathrm{t}) / \mathrm{B} 1_{\mathrm{tr}}(\mathrm{t}) / \mathrm{M}_{\text {res }}(\mathrm{t}) / \mathrm{B} 1_{\text {res }}(\mathrm{t}) / \mathrm{B} 2_{\text {res }}(\mathrm{t})$ & 84 & 6658.36 & 5452.41 & 13.16 & 0.00 \\
\hline $3 \mathrm{~A}$ & $\mathrm{M}(\mathrm{t}) / \mathrm{B} 1(\mathrm{t}) / \mathrm{B} 2(\mathrm{~T})$ & $\mathrm{M}_{\mathrm{tr}}(\mathrm{t})=\mathrm{B} 1_{\mathrm{tr}}(\mathrm{t}) / \mathrm{M}_{\text {res }}(\mathrm{t}) / \mathrm{B} 1_{\text {res }}(\mathrm{t}) / \mathrm{B} 2_{\text {res }}(\mathrm{t})$ & 76 & 6680.55 & 5454.02 & 14.77 & 0.00 \\
\hline $4 \mathrm{~A}$ & $M(t) / B 1(t) / B 2(T)$ & $\mathrm{M}_{\mathrm{tr}}(\mathrm{t}) / \mathrm{B} 1_{\text {tr }}(\mathrm{t}) / \mathrm{M}_{\text {res }}(\mathrm{t})=\mathrm{B} 1_{\text {res }}(\mathrm{t})=\mathrm{B} 2_{\text {res }}(\mathrm{t})$ & 64 & 6751.21 & 5486.10 & 46.85 & 0.00 \\
\hline $5 \mathrm{~A}$ & $M(t) / B 1(t) / B 2(T)$ & $\mathrm{M}_{\mathrm{tr}}(\mathrm{t}) / \mathrm{B} 1_{\text {tr }}(\mathrm{t}) / \mathrm{M}_{\text {res }}(\mathrm{t}) / \mathrm{B} 1_{\text {res }}(\mathrm{t})=\mathrm{B} 2_{\text {res }}(\mathrm{t})$ & 73 & 6675.87 & 5444.31 & 5.06 & 0.05 \\
\hline $6 \mathrm{~A}$ & $M(t) / B 1(t) / B 2(T)$ & $\mathrm{M}_{\mathrm{tr}}(\mathrm{t})=\mathrm{B} 1_{\mathrm{tr}}(\mathrm{t}) / \mathrm{M}_{\text {res }}(\mathrm{t}) / \mathrm{B} 1_{\text {res }}(\mathrm{t})=\mathrm{B} 2_{\text {res }}(\mathrm{t})$ & 65 & 6698.78 & 5446.49 & 7.25 & 0.02 \\
\hline $7 \mathrm{~A}$ & $\mathrm{M}(\mathrm{t}) / \mathrm{B} 1(\mathrm{t}) / \mathrm{B} 2(\mathrm{~T})$ & $\mathrm{M}_{\mathrm{tr}}(\mathrm{t}) /+/ \mathrm{B} 1_{\mathrm{tr}}(\mathrm{t}) /+/ \mathrm{M}_{\text {res }}(\mathrm{t}) /+/ \mathrm{B} 1_{\text {res }}(\mathrm{t})=\mathrm{B} 2_{\text {res }}(\mathrm{t})$ & 43 & 6747.61 & 5441.25 & 2.00 & 0.21 \\
\hline 8A & $M(t) / B 1(t) / B 2(T)$ & $\mathbf{M}_{\mathrm{tr}}(\mathbf{t})=\mathbf{B} \mathbf{1}_{\mathrm{tr}}(\mathbf{t}) /+/ \mathbf{M}_{\text {res }}(\mathbf{t}) /+/ \mathbf{B} 1_{\text {res }}(\mathbf{t})=\mathbf{B} 2_{\text {res }}(\mathbf{t})$ & 42 & 6747.61 & 5439.25 & 0.00 & 0.58 \\
\hline $9 \mathrm{~A}$ & $\mathrm{M}(\mathrm{t}) / \mathrm{B} 1(\mathrm{t}) / \mathrm{B} 2(\mathrm{~T})$ & $\mathrm{M}_{\mathrm{tr}}(\mathrm{t})=\mathrm{B} 1_{\mathrm{tr}}(\mathrm{t}) /+/ \mathrm{M}_{\text {res }}(\mathrm{t}) /+/ \mathrm{B} 1_{\text {res }}(\mathrm{t}) /+/ \mathrm{B} 2_{\text {res }}(\mathrm{t})$ & 43 & 6748.626 & 5442.05 & 2.80 & 0.14 \\
\hline $10 \mathrm{~A}$ & $\mathrm{M}(\mathrm{t}) / \mathrm{B} 1(\mathrm{t}) / \mathrm{B} 2(\mathrm{~T})$ & $\mathrm{M}_{\mathrm{tr}}(\mathrm{t})=\mathrm{B} 1_{\text {tr }}(\mathrm{t}) /+/ \mathrm{M}_{\text {res }}(\mathrm{t})=\mathrm{B} 1_{\text {res }}(\mathrm{t})=\mathrm{B} 2_{\text {res }}(\mathrm{t})$ & 41 & 6808.58 & 5485.64 & 46.39 & 0.00 \\
\hline $11 \mathrm{~A}$ & $\mathrm{M}(\mathrm{t}) / \mathrm{B} 1(\mathrm{t}) / \mathrm{B} 2(\mathrm{~T})$ & $\mathrm{M}_{\mathrm{tr}}=\mathrm{B} 1_{\mathrm{tr}} / \mathrm{M}_{\mathrm{res}} / \mathrm{B} 1_{\text {res }}=\mathrm{B} 2_{\text {res }}$ & 29 & 6863.74 & 5505.41 & 66.17 & 0.00 \\
\hline
\end{tabular}


(a)

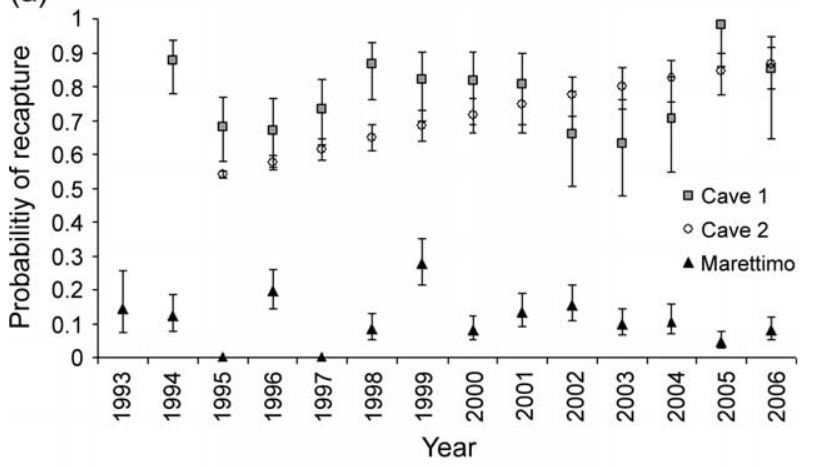

(b)

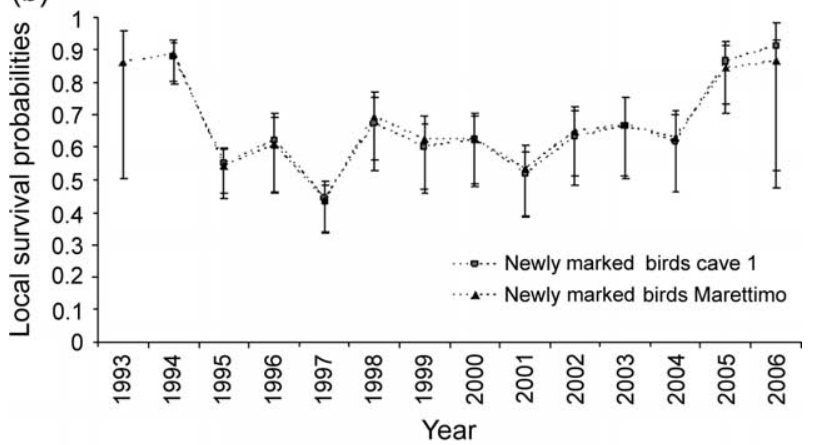

(c)

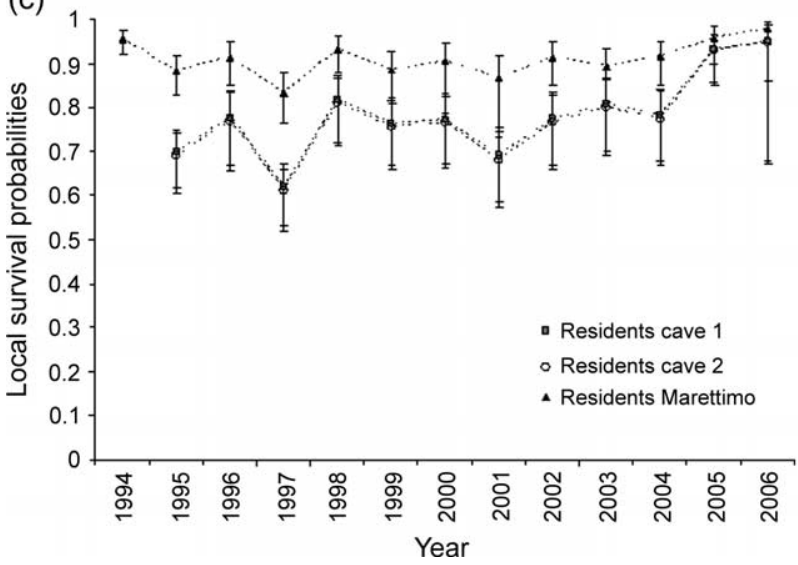

Figure 3. Model averaged estimates on recapture (a) and local survival of newly marked birds (b) and local survival of residents (c) probabilities of European storm petrels marked as adults, breeding at Marettimo, Italy, and caves 1 and 2 at Benidorm Island, Spain. Model averaged estimates were obtained through capture -recapture modelling (Table 2).

biased (the posterior probability of the proportion of males being larger than 0.5 was 0.90 ).

\section{Population matrix modelling}

Projections from population models indicated contrasting trends among the colonies, although the differences between the long-term deterministic growth rates were not statistically significant due to the large $95 \%$ confidence intervals (mean (and SE): 0.89 (0.05), 0.98 (0.03), 0.97 (0.04) for cave 1 , cave 2 and Marettimo, respectively). Surprisingly, the different combinations of recruitment, survival and breeding success estimates from the three colonies led to similar population growth rates (respecting confidence intervals). Estimates for Marettimo and cave 2 were not statistically different from a stable population, i.e. $\lambda=1(p=0.45$ and $p=51$, respectively). Parameter estimates from cave 1 were not high enough to reach stability $(p=0.03)$. The population growth rate at all colonies showed the greatest sensitivity to changes in adult survival (Supplementary material Appendix 2, Table S2). The highest sensitivity was to survival of birds aged $>5 \mathrm{yr}$ (sensitivity $=0.69,0.85$ and 0.80 for Marettimo, cave 1 and cave 2 respectively). As predicted from life-history theory, sensitivity to juvenile survival and fertility was low in all colonies. As data on breeding success for Marettimo colony was not available and in order to avoid parameter borrowing from cave 2 , we performed a new matrix model (results not shown) in which breeding success at Marettimo for birds aged 1 and 2 was fixed to 0 and breeding success for older birds was fixed to 0.3 (a value in the low boundaries for this species in absence of perturbations caused by high predation). The lambda value obtained under this scenario was $0.933(\mathrm{SE}=0.035)$. As sensitivities for fertility were small, results did not change substantially. Estimated population growth rate was not different from a stable population $(\mathrm{p}=0.056)$.

\section{Discussion}

Provided herein are the first age-dependent estimates of survival, recruitment and breeding success for the vulnerable European storm petrel from three colonies in the Mediterranean basin. Robust estimates of demographic parameters are necessary for a conservation diagnosis of threatened species or populations and to provide guidelines for management actions (Morris and Doak 2002). In addition, the hypogeous nesting habit of the species makes it difficult to obtain reliable estimates of population size and population dynamics can only be approached by means of individual-based demographic data (Oro et al. 2004b).

Our results showed important similarities between colonies, but also differences in recruitment processes and survival probabilities. As expected, the analyses of birds marked as fledglings indicated that survival, recruitment and breeding success probabilities increased with age. In agreement with the general findings on long-lived birds, youngest individuals had a low breeding success and showed a low local survival (Forslund and Pärt 1995, Tavecchia et al. 2001, Breton et al. 2006). At present, we do not know if the low survival by the youngest birds resulted from natal dispersal or mortality, since capture-recapture models do not distinguish these two possibilities without additional information, e.g. recoveries of dead birds (Lebreton et al 1992, Breton et al. 2006). Accession to reproduction (recruitment) varied among colonies: in Marettimo birds began to reproduce earlier than in the other two colonies but the full recruitment was attained later. We do not have an explanation for these differences: a first cause may be a difference in predatory pressure among the colonies which may have delayed accession to reproduction in young inexperienced prospectors (Rodd and Reznick 1997, Oro et al. 2005). This would explain why in the colony where predation by yellow-legged- 
Table 3. a) Modelling age- and colony-dependent variation in the breeding success at caves 1 and 2 at Benidorm Island, Spain, noted B1 and B2. Notation as in Table 1. Note that $3 \mathrm{yr}$ old was the earliest age of first reproduction at Benidorm colonies. Model with the higher $w$ is in bold. b) Age-dependent breeding success estimates and standard error of European storm petrel marked as fledglings and subsequently breeding at Benidorm Island obtained though model averaging.

a)

\begin{tabular}{|c|c|c|c|c|c|c|}
\hline Model & Breeding success & $\mathrm{np}$ & dev & QAICC & $\triangle \mathrm{QAICC}$ & w \\
\hline 1 & $\mathrm{~B} 1=\mathrm{B} 2$ & 1 & 165.80 & 169.80 & 3.20 & 0.05 \\
\hline 2 & B1/B2 & 2 & 165.20 & 171.20 & 4.60 & 0.02 \\
\hline 3 & $\mathrm{~B} 1 \mathrm{a}(3,4: 13)=\mathrm{B} 2 \mathrm{a}(3,4: 13)$ & 2 & 160.80 & 166.80 & 0.20 & 0.21 \\
\hline 4 & $\mathrm{~B} 1 \mathrm{a}(3,4: 13) /+/ \mathrm{B} 2 \mathrm{a}(3,4: 13)$ & 3 & 159.60 & 166.60 & 0.00 & 0.24 \\
\hline 5 & $\mathrm{~B} 1 \mathrm{a}(3,4: 13) / \mathrm{B} 2 \mathrm{a}(3,4: 13)$ & 4 & 157.70 & 167.70 & 1.10 & 0.14 \\
\hline 6 & B1 a(3_4,5:13)=B2 a(3_4,5:13) & 3 & 160.70 & 168.70 & 2.10 & 0.08 \\
\hline 7 & B1 a $\left(3 \_4,5: 13\right) /+/$ B2 $\mathrm{a}\left(3 \_4,5: 13\right)$ & 4 & 158.60 & 168.60 & 2.00 & 0.09 \\
\hline 8 & B1 a(3_4,5:13)/B2 a(3_4,5:13) & 6 & 157.40 & 171.40 & 4.80 & 0.02 \\
\hline 9 & B1 a(3_5,6:13) = B2 a(3_5,6:13) & 4 & 159.60 & 169.60 & 3.00 & 0.05 \\
\hline 10 & B1 a $\left(3 \_5,6: 13\right) /+/$ B2 a $\left(3 \_5,6: 13\right)$ & 5 & 157.60 & 169.60 & 3.00 & 0.05 \\
\hline 11 & B1 a(3_5,6:13)/B2 a(3_5,6:13) & 8 & 155.90 & 173.90 & 7.30 & 0.01 \\
\hline 12 & B1 a(3_6,7:13)=B2 a(3_6,7:13) & 5 & 159.50 & 171.50 & 4.90 & 0.02 \\
\hline 13 & B1 a(3_6,7:13)/+/B2 a $\left(3 \_6,7: 13\right)$ & 6 & 157.50 & 171.50 & 4.90 & 0.02 \\
\hline 14 & B1 a(3_6,7:13)/B2 a(3_6,7:13) & 10 & 155.40 & 177.40 & 10.8 & 0.00 \\
\hline
\end{tabular}

b)

\begin{tabular}{lrcc}
\hline Colony & Age & Breeding success & SE \\
\hline Cave 1 & 3 & 0.22 & 0.07 \\
Cave 1 & 4 & 0.56 & 0.07 \\
Cave 1 & 5 & 0.56 & 0.07 \\
Cave 1 & -13 & 0.54 & 0.06 \\
Cave 2 & 3 & 0.31 & 0.11 \\
Cave 2 & 4 & 0.59 & 0.08 \\
Cave 2 & 5 & 0.60 & 0.07 \\
Cave 2 & $6-13$ & 0.58 & 0.06 \\
\hline
\end{tabular}

gulls was high individuals tended to recruit later, but it would not explain why in this colony the full recruitment was attained faster than Marettimo, where predation was thought to be very low. A further possible cause is that suitable breeding sites may not be equally available due to differences in density-dependence at each colony (Frederiksen et al. 2005, Tavecchia et al. 2008) affected by the existence of artificial nest-boxes at Benidorm. A third possible, nonexclusive explanation is that food resources are more abundant around Marettimo leading to improved body conditions relative to Benidorm and earlier recruitment, but at the moment we have no data to support this hypothesis.

Birds marked as fledglings (older than $2 \mathrm{yr}$ at Marettimo and 3 at Benidorm) clearly had a higher average survival probability than birds marked as adults. This reflects the yearly variation in survival and the temporal window of the analysis. Data from birds marked as fledglings came mainly from the last 4-6 yr of the study when the probability of survival was higher (Fig. 3), especially at Benidorm Island where in those years a selective culling program on yellowlegged-gulls was carried out to reduce predation pressure (Sanz et al. 2005, Sanz-Aguilar et al. 2009). Survival probabilities of birds marked as adults varied over time (not assessed in analysis of birds marked as fledglings) and among colonies, the exception being the survival of birds in caves 1 and 2 at Benidorm (narrow spatial scale), which appeared to be similar in all years. However differences between Marettimo and Benidorm (broad spatial scale) seemed to disappear near the end of the study when survival was similar among colonies (Fig. 3). These and published results (Oro et al. 2005, Tavecchia et al. 2008, Sanz-Aguilar et al. 2009) suggest that predation by yellow-legged-gulls may be the principal factor influencing differences in survival among colonies in this long-lived species. Other factors such as climatic conditions or food availability around the colonies or in the wintering grounds could generate differential additive mortality between the Italian and the Spanish colonies (Frederiksen et al. 2005).

Population models suggested that different age-dependent patterns of demographic parameters can lead to similar population growth rates. This is the case, for example, between the colony of Marettimo (where birds attained full recruitment the latest but started to reproduce the earliest) and cave 2 at Benidorm (where birds recruited later but experienced a slightly higher local survival). In both cases, long-term model projections indicated a stable population, whereas the model from cave 1 at Benidorm (where predation was higher and the buffering mechanisms limited, Ferrer et al. 2004, Grimm et al. 2005) indicated a declining trend. The difference in population growth rates was mainly caused by adult survival rather than by patterns of recruitment, to which population growth rate had a lower sensitivity. And as reflected in this result, the most sensitive parameter in terms of population growth rate was adult survival, in accordance with evidence on other studies from long-lived organisms (Saether and Bakke 2000). 
The greater variability was also found in the parameter that less influences average individual fitness: the highest population growth rates were found at the colonies with the highest survival even though they had different recruitment patterns. Our population matrix models were built using data from birds marked as fledglings that recruited at the end of the study when survival was generally high, at least at Benidorm, because the predation by the yellow-legged-gull was experimentally reduced (Sanz-Aguilar et al. 2009). In this respect our model describes an optimistic scenario as average value of survival before the experiment was probably lower. It may be possible that under high predation pressure of the yellow-legged-gull, storm petrel populations are likely to go extinct in the long term due to reduction in adult survival probabilities. In fact, results indicate a declining trend in the cave 1 population, although this decline might be buffered by immigration, which was not considered in the model, or by management actions designed to enhance petrel's adult survival, like the periodic removal of specialist gulls (Oro et al. 2005, Sanz et al. 2005, Sanz-Aguilar et al. 2009). Further studies should focus on environmental predictors (e.g. predation pressure, food and nest-site availability) of demographical traits and immigration-emigration mechanisms at metapopulation scale to be able to set up conservation actions at large geographical scales (Breton et al. 2006).

Acknowledgements - We would like to formally acknowledge the many people who participated in the field work over the years. We are indebted to the ward and Environmental Monitoring Service of Benidorm Island (Serra Gelada Natural Park - Generalitat Valenciana) and Leonardo Parisi (Marettimo). Santiago García and María Marín sexed the birds. Alejandro Martínez-Abraín helped with Bayesian analysis. Roger Pradel, Howard Townsend and three anonymous referees made very constructive comments on this manuscript. A.S. was supported by a postgraduate grant (Ref. AP2004-1128) of the Spanish Ministry of Science, which also funded the study through several grants (refs. BOS200301960, CGL2006-04325/BOS).

\section{References}

Amstrup, S. C. et al. 2005. Handbook of capture-recapture analysis. - Princeton Univ. Press.

Breton, A. R. et al. 2006. Encounter, survival, and movement probabilities from an Atlantic puffin (Fratercula arctica) metapopulation. - Ecol. Monogr. 76: 133-149.

Burnham, K. P. and Anderson, D. R. 2002. Model selection and inference, a practical information-theoretic approach. - Springer.

Cam, E. et al. 2005. Earlier recruitment or earlier death? On the assumption of equal survival in recruitment studies. - Ecol. Monogr. 75: 419-434.

Caswell, H. 2001. Matrix population models. - Sinauer.

Choquet, R. et al. 2004. M-SURGE: new software specifically designed for multistate capture recapture models. - Anim. Biodivers. Conserv. 27: 207-221.

Choquet, R. et al. 2005. U-CARE 2.2. User manual. - CEFE, Montpellier, France, <http://ftp.cefe.cnrs.fr/biom/ soft-CR/>.
Choquet, R. et al. 2006. M-SURGE 1.8. User manual. - CEFE, Montpellier, France <http://ftp.cefe.cnrs.fr/biom/ soft-CR/>.

Clobert, J. et al. 1994. The estimation of age-specific breeding probabilities from recaptures or resightings in vertebrate populations: II. Longitudinal models. - Biometrics 50: 375-387.

Coulson, T. et al. 1999. Small-scale spatial dynamics in a fluctuating ungulate population. - J. Anim. Ecol. 68: 658-671.

de León, A. and Mínguez, E. 2003. Occupancy rates and nesting success of European storm-petrels breeding inside artificial nest-boxes. - Sci. Mar. 67: 109-112.

Ferrer, M. et al. 2004. Density-dependent age of first reproduction as a buffer affecting persistence of small populations. - Ecol. Appl. 14: 616-624.

Forslund, P. and Pärt, T. 1995. Age and reproduction in birds - hypothesis and test. - Trends Ecol. Evol. 10: 374-378.

Frederiksen, M. and Bregnballe, T. 2001. Conspecific reproductive success affects age of recruitment in a great cormorant, Phalacrocorax carbo sinensis, colony. - Proc. R. Soc. B 268: 1519-1526.

Frederiksen, M. et al. 2005. Inter-population variation in demographic parameters: a neglected subject? - Oikos 111: 209-214.

Gaillard, J. M. et al. 2000. Temporal variation in fitness components and population dynamics of large herbivores. - Annu. Rev. Ecol. Syst. 31: 367-393.

Griffiths, R. et al. 1998. A DNA test to sex most birds. - Mol. Ecol. 7: 1071-1076.

Grimm, V. et al. 2005. Importance of buffer mechanisms for population viability analysis. - Conserv. Biol. 19: 578-580.

Hanski, I. and Gilpin, M. E. 1997. Metapopulation biology: ecology, genetics and evolution. - Academic Press.

Hilton, B. J. R. and Miller, M. W. 2003. Annual survival and recruitment in a ruby-throated hummingbird population, excluding the effect of transient individuals. - Condor 105: 54-62.

Lande, R. 1988. Demographic models of the northern spotted oswl (Strix occidentalis caurina). - Oecologia 75: 601-607.

Lebreton, J. D. et al. 1992. Modeling survival and testing biological hypothesis using marked animals: a unified approach with case studies. - Ecol. Monogr. 62: 67-118.

Levin, S. A. 1981. The role of theoretical ecology in the description and understanding of populations in heterogeneous environments. - Am. Zool. 21: 865-875.

Martin, J. L. et al. 2000. Black rats, island characteristics, and colonial nesting birds in the Mediterranean: consequences of an ancient introduction. - Conserv. Biol. 14: 1452-1466.

McCulloch, C. E. and Searle, S. R. 2001. Generalized, linear, and mixed models. - Wiley.

McNamara, J. M. and Houston, A. I. 1996. State dependent life histories. - Nature 380: 215-221.

Morgan, B. J. T. 2000. Applied stochastic modelling. - Arnold.

Morris, W. F. and Doak, D. F. 2002. Quantitative conservation biology theory and practice of population viability analysis. - Sinauer.

Newton, I. 1989. Lifetime reproduction in birds. - Academic Press.

Oro, D. 2008. Living in a ghetto within a local population: an empirical example of an ideal despotic distibution. - Ecology 89: 838-846.

Oro, D. and Pradel, R. 2000. Determinants of local recruitment in a growing colony of Audouin's gull. - J. Anim. Ecol. 69: 119-132. 
Oro, D. et al. 2004a. Influence of food availability on demography and local population dynamics in a long-lived seabird. - Proc. R. Soc. B 271: 387-396.

Oro, D. et al. 2004b. Modelling demography and extinction risk in the endangered Balearic shearwater. - Biol. Conserv. 116: 93-102.

Oro, D. et al. 2005. Estimating predation on breeding European storm-petrels (Hydrobates pelagicus) by yellow-legged gulls (Larus michahellis). - J. Zool. 265: 421-429.

Pradel, R. et al. 1997. Capture-recapture survival models taking account of transients. - Biometrics 53: 88-99.

Reznick, D. A. et al. 1990. Experimentally induced life-history evolution in a natural population. - Nature 346: 357-359.

Rodd, F. H. and Reznick, D. N. 1997. Variation in the demography of guppy populations: the importance of predation and life histories. - Ecology 78: 405-418.

Saether, B. E. and Bakke, O. 2000. Avian life history variation and contribution of demographic traits to the population growth rate. - Ecology 81: 642-653.

Sanz, A. et al. 2005. Scientifically-based management solves conflict between European storm petrels and their facultative predator at minimum cost. - Ecol. Medit. 31: 104-105.

Download the Supplementary material as file E5596 from $<$ www.oikos.ekol.lu.se/appendix $>$.
Sanz-Aguilar, A. et al. 2008. The cost of reproduction and experience-dependent vital rates in a small petrel. - Ecology 89: 3195-3204.

Sanz-Aguilar, A. et al. 2009. Evidence-based culling of a facultative predator: efficacy and efficiency components. - Biol. Conserv. 142: 424-431.

Tavecchia, G. et al. 2001. Sex- and age-related variation in survival and the cost of first reproduction in greater flamingos. - Ecology 82: 165-174.

Tavecchia, G. et al. 2005. Predictors of reproductive cost in female Soay sheep. - J. Anim. Ecol. 74: 201-213.

Tavecchia, G. et al. 2008. Living close, doing differently: smallscale asynchrony in demographic parameters in two species of seabirds. - Ecology 89: 77-85.

Valvo, F. L. and Massa, B. 2000. Some aspects of the population structure of storm petrels Hydrobates pelagicus breeding on a Mediterranean island. - Ringing Migr. 20: 125-128.

Warham, J. 1990. The petrels. Their ecology and breeding systems. - Academic Press.

Weimerskirch, H. 2002. Seabird demography and its relationship with the marine environment. - In: Schreiber, E. A. and Burger, J. (eds), Biology of marine birds. CRC Press, pp. $115-135$. 